\title{
KS. ANDRZEJ PERZYŃSKI, WŁOSKA ANTROPOLOGIA TEOLOGICZNA. STUDIUM HISTORYCZNO- DOGMATYCZNE, ŁÓDŹ 2012, SS. 404
}

Biorąc do ręki liczne włoskojęzyczne publikacje teologiczne, dziś niejednokrotnie bezpośrednio tłumaczone także na język polski, trzeba w pierwszej kolejności pamiętać o tym, że pochodzą one z „wielkiej stoczni” kreatywnego myślenia opartego na Słowie wiary i konkretnej historii myśli i życia narodu (B. Forte). Tym zaś, co teologii włoskiej nadaje szczególnej oryginalności, jest fakt, że po przezwyciężeniu hegemonii neoscholastycznego ujęcia jest ona wreszcie „myślana po włosku” (G. Barbaglio, G. Bof, S. Dianich).

Ta niezwykle ważna świadomość towarzyszyła zapewne ks. dr. hab. Andrzejowi Perzyńskiemu w wyborze zarówno środowiska, jak i w opracowaniu wiodącego tematu, jakim jest według samego tytułu - włoska antropologia teologiczna. Choć pytania egzystencjalne: kim jest człowiek? Skąd pochodzi? Jaki jest sens jego życia i ludzkiej aktywności? - jak dostrzega Autor, od zawsze towarzyszyły człowiekowi (s. 148), to jednak do ich ponownego podjęcia i próby odpowiedzi na nie skłania dziś zwłaszcza antropologiczny klimat naszych czasów. Nie pomniejszając znaczenia różnych aspektowych ujęć człowieka w wymiarze jego życia biologicznego, duchowego, etnicznego, kulturowego, społecznego, dziś potrzeba szczególnie takiego ujęcia prawdy o człowieku, które ukaże go w jego całości, w wymiarze osoby i jej niezaprzeczalnej godności. Stąd potrzeba antropologii teologicznej, która korzystając $\mathrm{z}$ aspektowych i wycinkowych ujęć człowieka, a zwłaszcza $\mathrm{z}$ antropologii filozoficznej, jest w stanie ukazać pełną i integralną prawdę o człowieku w jego relacji do Boga i ofiarowanego mu przez Niego zbawienia.

Monografia ks. dr. hab. Andrzeja Perzyńskiego, któremu teologia włoska jest doskonale znana (godzi się przypomnieć choćby - Metoda teologiczna wedtug szkoły mediolańskiej. Studium historyczno-dogmatyczne, Warszawa 2006, ss. 399), składa się z pięciu części, które zasługują na miano dopełniających się „odsłon” tej wielkiej i niezwykłej zarazem tajemnicy, jaką jest człowiek. Dla ukazania szerszego kontekstu rozważań o człowieku Autor stopniowo i konsekwentnie rozwija swoje przemyślenia, przywołując najpierw znaczące osiągnięcia filozofii, która pomimo swych ograniczeń wniosła trwały wkład w myśl chrześcijańską. Antropologia chrześcijańska, o czym świadczy najlepiej kategoria osoby, łączy w sobie dwa porządki refleksji teologicznej i filozoficznej (s. 191). Kolejnym niezwykle ważnym etapem w kształtowaniu się współczesnej włoskiej antropologii teologicznej był i poniekąd wciąż pozostaje wkład Vaticanum II. Przechodząc zaś do różnych wymiarów włoskiej antropologii, Autor w oparciu o analizowane źródła ukazuje 
tajemnicę człowieka w relacji do misterium Chrystusa (wymiar chrystocentryczny), do zbawienia obecnego w historii (wymiar historiozbawczy) oraz w świetle łaski - darmowej inicjatywy Boga (wymiar charytologiczny). Całość monografii wieńczą: zakończenie, wykaz skrótów, bibliografia tematyczna, włoski, angielski i hiszpański spis treści wraz z podsumowaniem oraz indeks autorów i haseł.

Teologia współczesna uprawiana zwłaszcza w obrębie chrześcijaństwa zachodniego jest $\mathrm{w}$ swej istocie rozdrobniona i ujmowana w ramach poszczególnych dziedzin teologii, a niejednokrotnie skoncentrowana wokół określonych zagadnień. Powstające wciąż nowe opracowania teologii stworzenia, teologii odkupienia, teologii łaski, teologii usprawiedliwienia czy teologii miłosierdzia - prowadzą w istocie do utraty jej syntetycznego, integralnego opracowania. Ta droga uprawiania teologii, choć niewątpliwie wyrasta ze słusznego założenia pogłębienia poszczególnych prawd i zagadnień teologicznych, ma jednak i swoje mniej pozytywne strony, a są nimi zwłaszcza brak jedności i całościowej wizji, a także fragmentaryczność. Na podstawie pogłębionej analizy współczesnych nurtów teologii ks. dr hab. Andrzej Perzyński w oparciu o swoje studium postuluje integralnie pojętą teologię człowieka.

W całościowym spojrzeniu na teologię człowieka godzi się w pierwszej kolejności przywołać wręcz nieśmiertelne słowa wielkiego Polaka, dziś świętego Jana Pawła II, który w swej pierwszej encyklice ujął jej podstawy w stwierdzeniu, że człowiek, który chce zrozumieć siebie samego musi z całą swoją tajemnicą zwrócić się do Chrystusa, „musi niejako w Niego wejść z sobą samym, musi sobie «przyswoić», zasymilować całą rzeczywistość Wcielenia i Odkupienia, aby siebie odnaleźć" (RH 10). A więc nie filozoficzne koncepcje starożytnych Greków i Rzymian ujmujące niezwykłość osoby w: etycznych pytaniach człowieka (Sokrates), koncepcji duszy (Platon), swoistości ludzkiego bytu (Arystoteles), pytaniach o sens ludzkiego życia i śmierci (stoicy) - ale „nowość” chrześcijaństwa ujmująca człowieka jako osobę przede wszystkim w jego relacji do Boga. Osobowa godność jest dana człowiekowi, ale i zadana, gdyż od samego człowieka zależy, czy przyjmie on i otworzy się w pełni na dar Bożego obdarowania.

Analiza współczesnej włoskiej antropologii prowadzi ks. dr. hab. Andrzeja Perzyńskiego do sześciu istotnych wniosków. Pierwszym z nich jest antropologiczne ujmowanie teologii, a więc takie traktowanie o Bogu i tajemnicy Chrystusa, które w niczym nie umniejsza właściwemu teologii teocentryzmowi. Samym epicentrum tej nie zawsze łatwej do uchwycenia relacji winno być wydarzenie Chrystusa, Jego człowieczeństwo, które ogarnia wszystkich ludzi. Drugi z kolei element charakterystyczny dla włoskiej antropologii koncentruje się wokół przestrzeni wewnętrznej zażyłości człowieka z Bogiem, sięgającej podstawowej prawdy objawionej, jaką jest stworzenie człowieka na obraz Boga (Rdz 1, 26-27). Pojęcie obrazu i podobieństwa Bożego już od najstarszych wieków było niezwykle ważne w refleksji teologicznej. To właśnie obraz i podobieństwo do Boga oddają najlepiej wyjątkowość człowieka w świecie stworzeń. Wśród wielu wypracowanych w historii koncepcji obrazu i podobieństwa na uwagę zasługuje ich scalające ujęcie, które uwydatnia zdolność człowieka do wolnego działania, dzięki władzom intelektualnym i wolnej woli. 
Zrozumienie pojęcia obrazu i samego człowieka jest możliwe tylko w odniesieniu do Prawzoru, a sama relacja przybiera wiele form: bezpośredni kontakt z Prawzorem, pamięć i oglądanie Boga (visio Dei), modlitwa, otwartość ludzkiego rozumu i wolności na Boży rozum i wolność. Ścisłe zespolenie antropologii z chrystologią uwydatnia trzeci ważny element antropologii włoskiej, jakim jest antropologiczny wymiar chrystologii. Prawda o człowieku historycznie wypowiada się w pełni w Jezusie Chrystusie, przez co Jezus z Nazaretu (universale concretum et singulare) jest zasadą, ośrodkiem i celem wszelkiej rzeczywistości. Czwarty element, a zarazem postulat, to uwydatnienie autonomii i wolności człowieka, który jest zdolny do dania odpowiedzi Bogu i do otwarcia się na Niego. Nie chodzi tu o absolutną autonomię człowieka i świata, ale o względną autonomię, o autonomię przyczyny wtórnej. Nie ma innej odpowiedzi bardziej właściwej na ludzkie pragnienie zrealizowania się, egzystencjalnego wypełnienia, jak tylko uświęcenie. Ta droga, a zarazem piąty element charakterystyczny włoskiej antropologii, jest całkowicie darmowa i przejawia się w przyjaźni i komunii z Bogiem. Im mniej człowiek jest skoncentrowany na sobie samym, tym bardziej staje się świątynią samego Trójjedynego Boga. W Bogu człowiek osiąga swoją eschatologiczną pełnię. Jego najgłębsze pragnienia zaspokaja obficie łaska Chrystusa, a przy tym nie niszczy ludzkich sił i możliwości. Ostatni, szósty element charakteryzujący włoską antropologię podkreśla wymiar daru. Uwydatnia się tu soborowe źródło inspiracji, zawarte zwłaszcza w słowach: „człowiek, będący na ziemi jedynym stworzeniem, którego Bóg chciał ze względu na nie samo, nie może się w pełni odnaleźć inaczej, jak tylko przez szczery dar z siebie samego" (KDK 24). Człowiek został stworzony i powołany do daru z siebie, a więc do miłości, która w najpełniejszym sensie jest tajemnicą samego Boga, czyli Trójjedyną Miłością.

Współczesną włoską antropologię teologiczną - jak dostrzega ks. dr hab. Andrzej Perzyński, cechuje wielka otwartość, co uznać należy za szczególnie ważne w dzisiejszym świecie i prowadzonym z nim dialogu. Tajemnicy człowieka nie da się zrozumieć bez Boga, gdyż losy Boga i człowieka zostały ze sobą bardzo ściśle związane. Tajemnica Boga i tajemnica człowieka to właściwie dwa wymiary jednej i tej samej refleksji teologicznej, które przenikają się i nawzajem uzupełniają w obrębie współczesnej włoskiej antropologii teologicznej.

Monografia ks. dr. hab. Andrzeja Perzyńskiego napisana językiem przystępnym i komunikatywnym, co nadaje jej szczególnego waloru, czyni z jej Autora przewodnika pewnego i godnego zaufania w tak istotnej dla człowiek kwestii, jaką jest jego zbawienie.

ks. Sylwester Jaśkiewicz 